\title{
IDENTITET OG LITTERATURHISTORIE
}

\author{
ANNE-MARIE MAI \\ University of Southern Denmark
}

ABSTRACT. The paper discusses the need for a renewal of literary historiography and presents different strategies for new historical readings that can generate interest in older literature. Students at the Danish universities and high schools are supposed to have a solid knowledge of literary classics and the methods of historical reading. In a Danish context the school's task to form and develop young people have been linked to the experience of reading literature and knowing literary history. But the older literature seems to have become a compulsory reading which students want over with as quickly as possible. It is a big problem since the European postnational societies require a historical understanding of cultural values and the sources of these values. Literature gives the readers the opportunity to see and interpret themselves in relation to their surroundings, to meet the strange and unknown and to empathize with other people's thoughts and ideas. Literature creates a special feeling of language and an understanding of how linguistic meaning is formed. The paper presents discussions of literary historiography and new approaches to literary history.

\section{IDENTITET OG LITTERATURHISTORIE 1.1 HISTORISK LÆSNING SOM UDFORDRING}

I Danmark skrives der ikke så mange universitetsopgaver inden for området, litteraturen før 1960, som en litteraturprofessor med speciale i litteraturhistoriografi kunne ønske. ${ }^{1}$ Kun mellem 6 og $10 \%$ af danske universitetsspecialer omhandler litteratur før

${ }^{1}$ Den foreliggende artikel er en bearbejdning af et teoretisk afsnit i min udgivelse, Hvor litteraturen finder sted, vol.I-III (Mai 2010-2011), og forskellige tidligere arbejder: Historier frem for kanoner - Refleksioner over litteraturhistorieskrivning og historisk lasning (Mai 2009a) samt Hvor litteraturen finder sted: - tanker om litteraturhistorieskrivning (Mai 2009b). 
$1960^{2}$, og flere af de specialer, der faktisk skrives om "det ældre stof" beskæftiger sig med H. C. Andersen og Herman Bang. Både Andersen og Bang er selvfølgelig fremragende internationale klassikere, som litterater aldrig bliver færdige med at fordybe sig i. Men den danske litterære kulturarv går en vanskelig fremtid $\mathrm{i}$ møde, hvis der i realiteten kun er meget få specialister, der har lyst til at fordybe i det ældre stof, og hvis de undervisere, universitetsuddannelserne sender ud i verden for at undervise gymnasieelever og lærere i folkeskolen, konsekvent har fravalgt frivilligt at beskæftige sig med litteratur før 1960.

Hvis man ser på bestemmelserne over, hvad der er formålet med danskundervisningen i den danske gymnasieskole, kan man hæfte sig ved, at arbejdet med både ældre og nyere tekster indgår i uddannelsens dannelsesformål:

Danskfaget tjener på en gang et dannelsesmæssigt og et studieforberedende formål. I
arbejdet med afdækning af ældre og nyere teksters betydning anskuet i et sprogligt,
litterært og kulturelt perspektiv skærpes elevernes kritisk-analytiske sans. Dermed bidrager
faget til både at udvide elevernes dannelseshorisont og at styrke deres evne til at håndtere
informationer, gå bag om ordene og forstå disses indhold og nuancer. Kritisk-analytisk
sans og beherskelsen af et sikkert sprogligt udtryk fremmer elevens muligheder for at
orientere sig og handle i et moderne, demokratisk, globalt orienteret samfund.

Tekst- og litteraturlæsning skal være med til at danne eleverne og dermed give dem muligheder for at deltage i samfundslivet. Danskfagets kernestof er det sproglige, det litterære og det mediemæssige område, og eleverne skal "dokumentere kendskab til en bred repræsentation af centrale danske litterære værker gennem tiderne med perspektiv til litteraturen i Norden, Europa og den $\emptyset$ vrige verden" ${ }^{\prime}$. Det lyder sådan set lovende og løfterigt, at der er formuleret et sådant formål med undervisningen, og at undervisningen tager sigte på at være med til at give eleverne en identitet som borgerne i en moderne, global omverden. I litteraturundervisningen skal oplevelse, analyse og fortolkning bringes $\mathrm{i}$ samspil ved at forbinde sproglige, historiske og æstetiske synsvinkler. Dette formål og denne strategi skal medvirke til at eleverne kan udvikle sig som mennesker, danne deres identitet og kunne begå sig i det nutidige samfund.

${ }^{2}$ Min vurdering baserer sig på en gennemgang af oversigter over specialer fra 2007-2011 udarbejdet inden for området nordisk litteratur og sprogvidenskab ved Københavns Universitet, Aarhus Universitet og Syddansk Universitet. Specialeoversigterne er tilgængelige på uddannelsernes hjemmesider.

3 Gymnasiebekendtgørelsen for faget Dansk på STX, 2010, offentliggjort på hjemmesiderne ved Ministeriet for børn og undervisning: internetstedet: https://www.retsinformation.dk/Forms/R0710.aspx?id=132647\#B15

${ }^{4}$ Ibid. 
Men hvis vi på universitet har så få forskere, der intensivt beskæftiger sig med ældre litteratur, og hvis gymnasielærerne i deres studietid ikke har fået det ældre stof med sig i bagagen, kan det knibe med at indfri det fine formål. Det bliver i så tilfælde svært at få arbejdet med ældre tekster og ældre litteratur til at være et aktiv i dannelsesformålet og for identitetsudviklingen. Arbejdet med historisk læsning bliver her en virkelig udfordring.

\subsection{FARVEL TIL DEN NATIONALE KONSTRUKTION}

Det dannelses- og identitetsudviklingens formål, der er knyttet til litteraturlæsningen, har sit ophav i den romantiske filosofi og litteratur i slutningen af 1700-tallet og begyndelsen af 1800-tallet. Her stræbte man igennem litteraturen efter at belyse åndens, folkets og nationens historie. Historien bevægede sig i denne optik fra en fortidig storhedstid, over et nutidigt fald og frem mod en genkommen guldalder, og historien fik dermed et tydeligt, fortællende og kronologisk forløb. I dansk sammenhæng formidlede filosoffen og naturvidenskabsmanden Henrich Steffens det nye, dynamiske syn på historien i sine forelæsninger i København i 1801 (jf. Steffens 1996). I den romantiske optik rummer litteraturen et folks stræben efter at udtrykke sig selv og bidrage til en overnational universalkunst. Mennesket dannes som individ og udfolder sit eget åndelige potentiale i sin tilegnelse af historien om nationens litteratur. At læse litteraturhistorie er at få indsigt i en anden, åndelig natur, den store sammenhæng og den store nationale historie bag bunker af støvet materiale og gamle bøger. Litteraturhistorien er en national dannelsesroman, hvor læseren skuer sig selv fra barnets paradisiske liv, over ungdommens krise og frem til det voksne menneskes modne afklaring.

Den moderne romantiske litteraturhistorietænkning så netop sig selv som del af en bestræbelse på at overvinde en datidig åndelig krise, der ifølge Steffens havde skilt videnskab og poesi og gjort religionen til et mærkeligt fritsvævende monster. Romantikkens tænkning interesserede sig for historiens progression i et tidsligt forløb, men stræbte samtidig efter at komme ud over tiden og nå ind i mytologien, den gyldne tid før tiden og efter historien. Romantikkens historiesyn byggede således på en opfattelse af historien som et fald i forhold til myten. Historien var til for at overvindes. På dansk grund resulterede denne optik karakteristisk nok i, at den tidlige litteraturhistoriske fortælling blev bygget op over to højdepunkter: den mytologiske folkedigtning i form af eddadigtning, sagaer og ballader samt romantikkens gennembrud med Adam Oehlenschläger og Poul Martin Møller som nationale superstars. Man gik på jagt i arkiverne for - som den første danske litteraturhistoriker 
N.M. Petersen i 1867 sagde i en ny udgave af sit værk, Bidrag til den danske Literaturs Historie - at finde gode glemte frøkorn og ikke mindst for at se litteraturen i fostertilstanden (Petersen 1867:9): "Forskningen vil Enhed; den vil under et se, ikke blot Skabningen naar den er i sin fulde Væxt, men ogsaa dens Fremgang, ja den vil gjenskue den i sit Foster." N.M. Petersen ville med sit arbejde opvække den yngre slægt og give den litterære frø til fremtiden. For ham var det nutidens og fremtidens folkelige og nationale opgaver, det gjaldt om at løse.

I nutiden peger bestemmelserne af danskundervisningens formål på, at litteraturen må være medvirkende til at løse andre opgaver: især den postnationale opgave med at give eleverne muligheder for at leve og handle $\mathrm{i}$ et globalt orienteret samfund. Som national konstruktion er litteraturhistoriens tid forbi, men som en genre for store og små fortællinger om æstetiske værdier og kulturelle rødder har den stadig betydning. Det hænger sammen med litteraturens historie netop giver muligheder for at fortælle om, hvordan litteraturen er indgået $\mathrm{i}$ forskellige historiske sammenhænge, hvor mennesker helt grundlæggende har fors $\emptyset \mathrm{gt}$ at fortolke deres liv og muligheder, og hvordan litteraturbegrebet har forandret sig igennem tiderne.

Skønlitteraturen er en moderne foreteelse, og med nutidens digitale medier står vi over for en forandring af selve litteraturbegrebet. Ordkunsten har ikke længere blot den trykte bog som sit medie, men udformes i nutiden på helt nye medieplatforme og i kollektive genrer, som bryder med et romantisk forankret litteraturbegreb. Det identitetsfortolkende projekt har aldrig været mere pågående og krævende for mennesker end i nutiden, hvor identitet er blevet et performativ, som foregår i en stribe af sociale medier og kulturelle fora ${ }^{5}$. Frem for at erstatte en gammelnational konstruktion af litteraturhistorien med en nynational europæisk litteraturhistorie er der derfor brug for at fortælle om, hvordan ordkunsten er indgået i fortolkningssammenhænge i fortiden, der både er forskellige fra og ligner nutiden. Når adelsdamen Anne Krabbe i begyndelsen af 1600-tallet kastede sig over sit arbejde med en visebog, var det for at gøre sin herregård til et magthus og sig selv til en af egnes magtfulde adelsdamer. Teksterne indgik i hendes adelige og familiære selvforståelse ${ }^{6}$. Når nutidens unge "battler" med freestyle rap lægger de ikke åndelige sten til en herregård, men "performer" deres selvfølelse, sociale og kulturelle identitet igennem ordkunst. De gamle balladers form og tema lader sig sammenligne med nutidens på en måde, der giver indsigt $\mathrm{i}$ begge genrer og deres historie.

\footnotetext{
${ }^{5}$ Min argumentation ligger her i forlængelse af Judith Butlers diskussioner af performativ identitet i Butler (1990).

${ }^{6}$ Se nærmere i Mai (2010-2011 I:127ff).
} 


\section{BEHOV FOR FORNYELSE 2.1 LITTERATUR- OG KULTURKANONER}

Men skal den ældre litteraturs muligheder i forhold til identitet og dannelse komme til sin ret er der behov for en grundlæggende fornyelse. Vi står i fare for, at læsere, elever og studerende kun oplever litterær kulturarv som pensum og pligtstof. I en dansk sammenhæng er diverse kultur- og litteraturkanoner blevet $\mathrm{k} ø \mathrm{rt} \mathrm{i}$ stilling for at sikre velfærdssamfundets kulturarv. I skoler og på gymnasier fik vi i Danmark i 2004 den såkaldte undervisningskanon, der opregner 15 obligatoriske forfattere, som man skal læse mindst en tekst af. I 2004 fulgte Kulturkanon, der blev skudt i gang med bøger og internetmateriale om 12 værker indenfor hver enkelt kunstart. Litteraturen blev her repræsenteret med flere tekster, idet en lyrikantologi på 24 digte blev litteraturkanons nummer 12 .

Kulturkanon omtalte således ikke blot de centrale kunstnere, men udpegede en række kanoniske tekster. Både Undervisningskanon og Kulturkanon søger at gøre værker og forfattere aktuelle for samtiden. Man ser ud til at ville befri værker og forfattere for historiens st $\varnothing v$. Historiske forhold kan være interessante, men det er den almene kunstneriske kvalitet og menneskelige værdi, der prioriteres. Om folkeviserne hedder det: "Folkeviserne er stor kunst. De fortæller om levet liv, om konflikter, sammenhold, troskab, skæbne, kærlighed i et samfund af en helt anden struktur end det nuværende - og dog samme sted. Afsættet til drøftelser af det almenmenneskelige og det kulturbestemte er oplagte. Men først og fremmest skal viserne læses og opleves umiddelbart."7 Kanon-præsentationerne leverer små sammenfatninger af forfatterskabernes særtræk, og selv om man kan være kritisk over for den stadige betoninger af ligheder mellem nutid og fortid, er det en satsning på at fremme kendskabet til danske litterære klassikere. Men undervisnings- og kulturkanon indfrir ikke et meget stort behov for at forny litteraturhistorieskrivningen og skabe fremstillinger, der kan engagere nutidens læsere. I debatten om kanonerne tilkendegav flere gymnasieelever og studerende, at kanonerne lignede facitlister, som ikke udfordrede deres lyst til at selv at få på opdagelse $\mathrm{i}$ det historiske materiale. Kanonlisterne gjorde litteraturhistorien til et totalt kortlagt land, der ikke kunne byde på overraskelser.

\subsection{FORTÆLLING SOM METODE}

Mange undervisere på universiteter og gymnasier forsøger at afhjælpe på de unges vanskeligheder med få et historisk overblik og erhverve en fornemmelse af forskellene på historiske tider og kontekster ved at udarbejde

7 Undervisningskanon er offentliggjort hos Ministeriet for børn og undervisning: http://pub.uvm.dk/2004/kanon/kap06.html 
historiske skemaer med overblik over vigtige forfatterskaber, værker, historiske årstal og begivenheder. På skemaerne kan de unge læsere i al fald se tidsafstanden mellem 1789, 1945 og 1989 og få indskrevet Ludvig Holberg, Adam Oehlenschläger og Karen Blixen i forskellige historiske perioder. Jeg tror desværre ikke, at de historiske skemaer, som enhver underviser med respekt for sig selv, har i baghånden hjælper så meget. De går i glemmebogen, så snart eksamen er overstået. Det er min erfaring, at det er bedre at forsøge at gengive litteraturhistorien en fortællende dimension, frem for at reducere den til en årstalsliste.

Fortællingens betydning for menneskets mulighed for overhovedet at opnå en forståelse af historien er blevet analyseret af den franske filosof, Paul Ricœur, i den store trebinds afhandling, Temps et Récit (Tid og fortælling, 1983-1985, engelsk udgave i 1984-1988). Selv om her Ricœur forholder sig til historievidenskaben, er det oplagt, at der ud fra hans refleksioner er muligheder for også at gentænke fortællingen i litteraturhistorieskrivningen.

Det er Ricœurs synspunkt, at mennesket kun igennem fortællingen kan opnå en forståelse af fortiden. Mennesket forholder sig til to adskilte tidsdimensioner: dels sin egen eksistentielle tidsoplevelse, der binder fortid, fremtid og nutid tid til nu'et, dels den kosmiske, irreversible tid. Mennesket har derfor brug for fortællingens tredje tid for at kunne nærme sig en forståelse af det fortidige.

Når man bruger denne tankegang i forhold til historieskrivningen, kunne man tro, at det ville føre direkte tilbage til romantikkens store nationale fortællinger. Ricœur er dog i lighed med den postmoderne tænkning kritisk over for Hegels og romantikernes store fortælling om åndens sikre fremskridt igennem nationalhistorien. Alligevel fremhæver han fortællingen som en mulighed for mennesket til at formulere sin identitet, også kulturelt og litterært. Netop mellem de tilsyneladende uforenelige eksistentielle tidsoplevelser og videnskabens universelle kosmiske tid kan fortællingen etablere den tredje tid, en historisk tid.

Den historiske fortælling skaber sin tredje tid ved gennem kalenderen, generationsfølgen og det fortidige spor i arkiverne at koble den eksistentielle og den kosmiske tid. Der er ifølge Ricœur to slags fortællinger: den fiktive og den historiske fortælling. Mens den fiktive fortælling retter sig mod menneskets fantasi og det uvirkelige, retter den historiske fortælling sig mod det mulige og det virkelige. Men de to slags fortællinger låner selvfølgelig af hinanden. Historikeren har brug for sin fantasi i sine historiske undersøgelser ellers kan de slet ikke gennemføres, mens forfatteren inddrager større eller mindre fragmenter af det virkelige $i$ sit fiktionsunivers - sprogets henvisningsfunktion er blot et eksempel. Den historiske fortælling og den fiktive fortælling er forskellige, men de er ifølge Ricœur hele tiden i samtale med hinanden. 
Hvis man lader sig overbevise om Ricœurs bestemmelse af fortællingens betydning for menneskets historiske forståelse, er det klart, at litteraturhistorieskrivningen forfalder som forsknings- og formidlingsform, hvis den opgiver fortællingen. Den mister simpelthen sin erkendelsesmulighed og interesse. Hvis man følger Ricœurs tankegang, behøver man altså ikke som David Perkins i afhandlingen Is Literary History Possible? (1992) at slå beklagende ud hænderne og erklære, at litteraturhistorien er videnskabelig umulig, men alligevel ganske nyttig for at skabe en vis orden imellem forfatterskaber og tekster. Går man ind på Ricœurs ideer, bliver man nødt til at tænke i, hvordan fortællingen kan komme tilbage til litteraturhistorien uden at blive til en stor og totaliserende historie.

Hvordan man kan bevæge sig fra Ricœurs temmelig abstrakt-filosofiske bestemmelser af historisk tid og fortælling til et mere praktisk arbejde? Der er faktisk ganske langt, men man kan finde inspiration i Mario Valdés' kritiske diskussion af grundlaget for en ny litteraturhistorieskrivning. Hans bidrag til Rethinking Literary History. A Dialogue on Theory (Hutcheon \& Valdés 2002) er netop et forsøg på at gentænke historien i litteraturhistorien. Valdés inddrager selv Ricœurs opfattelse af tid og fortælling i sine overvejelser. Han fremhæver ud fra Ricœurs diskussioner, at det er vigtigt at se den historiske fortælling som en fortælling, der er en aktiv formning af materiale, ikke en passiv registrering af, hvad der en gang skete. Men vel at mærke en formning, der reflekterer over sine egne greb og studerer sin egen historicitet og sig selv som symbolsk form. Valdés bygger også i høj grad på Michel Foucaults begreb om arkivet og hans ide om bogen om et knudepunkt $i$ et enormt netværk af bøger og tekster. Bogen er ikke noget fast objekt; som enhed er bogen relativ og variabel.

Valdés argumenterer for at bryde de traditionelle nationale konstruktioner, der lader fremstillingen hvile på nationalsprogene, og i stedet ud fra en postkolonial tankegang arbejde med et begreb om "regioner" og "regional" litteratur. Valdés foreslår, at man strukturer en historisk læsning og fremstilling omkring de såkaldte "cultural nodes" og dermed inddrager en bredere kulturel kontekst. Man må opgive ideen om en totaliserende fremstilling, der forsøger at få alt med, og i stedet arbejde med knudepunkter i fremstillingen, som både kan være tidslige, f. eks. Berlin-murens fald i 1989, topografiske, f. eks. salonerne i 1700-tallets digtning, institutionelle, f. eks. striden mellem den gamle og den nye fløj i 1600-tallets franske akademi. Knudepunktet kan også være bestemte forestillinger i den litterære kultur, f. eks. ideen om digteren som nationalt ikon.

De forskellige kulturelle knudepunkter, som Valdés nævner, egner sig at skabe forløb, hvor både værker, forfattere, forlæggere og publikum kan optræde som agenter i forskellige fortællinger. Man kan arbejde med en kronologisk fremstilling og forestillingen om fortællingens begyndelse, midte 
og slutning, men behøver ikke at udvikle fortællingen i strikte og traditionelle periodebegreber eller reducere den til en -ismehistorie eller en tidstavle.

Der er ikke tvivl om, at der ud fra Valdés' læsning af Ricœurs ideer om tid og fortælling kan skrives fortællende litteraturhistorie, hvor selve historierne, også som gode, underholdende, morsomme og tragiske historier bliver centrale.

\section{EN STEDSLIG VENDING I LITTERATURHISTORIEN 3.1 STEDET SOM KNUDEPUNKT}

Ud fra Ricœurs og Valdés ideer har jeg udarbejdet mit nye bidrag til dansk litteraturs historie, Hvor litteraturen finder sted, vol. I-III (2010-2011). Jeg bruger her Valdés' begreb om "culturel nodes", og jeg er især interesseret $\mathrm{i}$ det knudepunkt, han kalder det stedslige knudpunkt, det vil sige litteratursteder - locations kunne man også kalde dem, hvor litteraturen er blevet produceret, formidlet, forbrugt og overleveret til efterkommere.

Jeg har udpeget en række steder, som kan danne udgangspunkt for studier af ældre litteratur: Det drejer sig om katedralen, herregården og hoffet, akademiet, præstegården og salonen. Jeg arbejder med disse litteratursteder, der hører hjemme i en europæisk sammenhæng, ud fra fortrinsvis danske eksempler: katedralen eksemplificeres af Ribe Domkirke, herregård og hof af Anne Krabbes Stenalt og Frederik IIs og Christian IVs hoffer, akademiet af Sorø Akademi (især under Holberg), præstegård og salon af Grundtvigs Udby præstegård og den dansk-tyske Friederike Bruns salon Sophienholm ved Bagsværd. Det 20. og 21. århundredes litteratursteder er i min fremstilling bladhuset, eksemplificeret ved dagbladet Politiken, grundlagt 1884, metropolen, eksemplificeret ved New York og internettet, eksemplificeret ved forskellige dansksprogede litteratursteder

Jeg ser disse litteratursteder som arkiver i Ricouers forstand. Jeg betragter dem dermed som en form for litterære arkiver, hvor litterære tekster udarbejdes, samles, bruges og kanoniseres i historiske kontekster. Det stedsforankrede arkiv er ikke blot en samling af bøger og dokumenter, men også et system af regler for litterære udsagns og teksters tilsynekomst, transformation og spredning.

Når de gælder middelalderens litteratursted, katedralen, benytter jeg mig den franske filosof Michel Foucaults stedsbegreb, heterotopi. Jeg ser katedralen er et virkeligt sted og en virkelig repræsentation af middelalderens magtfulde kirke, men den er også Guds hus, der anfægter alt jordisk og tidsligt og vender sig mod det usynlige, evige og himmelske. Katedralen udgør som litteratursted et arkiv, hvis princip er den dogmatiske udvælgelse af tekster. Der bliver her både mulighed for at se nærmere på de tekster, der kommer ind i arkivet og de tekster og litterære udtryk, der findes i omkredsen af det: alt fra 
legender, bibler og salmer til heksebekendelser og mundtlige folkelige genrer. Studiet omhandler således såvel arkivets koder som dets organisationsmåder og materiale. Denne pointe gælder for så vidt alle litteraturstederne.

Renæssancens herregård og hof er en litterær stedsverden $\mathrm{i}$ en anden forstand end den middelalderlige katedral. Med udgangspunkt $i$ den fænomenologiske stedsfilosof Edward S. Caseys begreb "stedsverden" er det muligt at arbejde med Anne Krabbes Stenalt og Frederik IIs og Christian IVs hof og de tekster, der indgår i skabelsen af herregård og hof som et litteraturog kultursted. Her er visebøger, salmer, ligprædikener, lejlighedsdigte, selvbiografier og historiebøger i fokus, og de centrale princip for forståelsen af litteraturens konfigurering i denne kontekst er ideen om den sjældne samling, der vidner om ejerens rang og byrd.

Oplysningtidens akademi, som vi på dansk grund ser realiseret i Holbergs Sorø, arbejder jeg med ud fra den russiske filosof Mikhail Bakhtins begreb om den litterære kronotop, som han udvikler i forbindelse med sine litterære genrestudier, og som han bestemmer som en meningsfuld forening af tids- og rumdimensioner i ét billede. Når kronotop-begrebet er interessant i forhold til Sorø Akademi hænger sammen med, at netop Sorø i en dansk sammenhæng er blevet et næsten fiktivt sted, der optræder i en række forskellige erindringer, digte og historiske romaner lige fra B. S. Ingemann i 1800-tallet til Henrik Stangerup i 1900-tallet. Som litteratursted er Akademiet på Holbergs tid konfigureret ud fra et encyklopædisk princip om at samle, systematisere og formidle al viden, og det bliver særligt spændende at fortælle om de forskellige biblioteker, der er til stede i Sorø og se på rejsebøger, historieskrivning, selvbiografier og tidsskrifter.

Salonen og præstegården analyserer jeg som litteratursteder ud fra den italiensk-amerikanske romanhistoriker Franco Morrettis begreb om geografisk kortlægning af litteraturhistorien. Jeg har valgt at se på spændingen mellem præstegård og salon i romantikkens tidsalder, som jeg eksemplificeres ud fra historien om Grundtvigs uvilje mod at forlade det litterære miljø i hovedstaden for at vende tilbage til præstegården i Udby og blive sin fars kapellan i begyndelsen af 1800-tallet. Som litteratursted var salonen konfigureret omkring universalpoesien, som man nærmede sig i en række genrer: digtet, samtalen, tableauet, recitationen eller vandringen.

Som litteratursted er præstegården konfigureret omkring det dannende skrift i form af både religiøs litteratur og nye opdragende og underholdende tidsskrifter, eksempelvis St. St. Blichers tidsskrifter. Man kan her tegne ganske interessante kort over trykkeriernes udbredelse og følge, hvordan de slår sig op på tre typer af publikationer: lokalaviser, religiøs litteratur og underholdene fortællinger, der finder aftagere både i præstegårde og blandt provinsens 
embedsmænd. Også tidsskrifternes subskriptionslister peger på præster og embedsmænd som vigtige aftagere af den nye lekture.

\subsection{MODERNE LITTERATURSTEDER}

I begyndelsen af det 20. århundrede bliver det moderne bladhus et litterært knudepunkt. Som litteratursted er bladhuset en begivenhed, der producerer og formidler moderne tekster. Bladhuset finder simpelthen konstant sted i det moderne bybillede og senere på de digitale portaler. Jeg arbejder her med Edward S. Caseys begreb om stedet som begivenhed. Bladhuset er en stedlig begivenhed i byverdenen. I nutiden er begivenheden en ramme om selve bygningen, hvor den elektroniske avis med sine lysende røde kæmpetyper lader en strøm af nyheder løbe hen over husets facade. Store bannere og plakater fuldender oplevelsen af et sted, der er skabt af og skaber begivenheder. Stedet som begivenhed præger hele husets indretning og opdeling i afdelinger og redaktioner, der fokuserer på hver deres type nyheder inden for politik, økonomi, internationale forhold, teater, bøger, kultur, viden og medier. Også litteraturens placering i bladhuset tilpasses begivenhedens karakter af at være enten noget enestående eller noget tilbagevendende. Litteraturen bliver en nyhed eller et fast indslag $\mathrm{i}$ avisens begivenhedsverden og får et nært forhold til de journalistiske genrer som føljetonen, reportagen og kronikken.

Storbyen eller metropolen bliver et andet af det 20. og 21. århundredes litterære knudepunkter. I de moderne og postmoderne metropolers liv og rytme indgår kunstner- og forfattermiljøer som særlige sociale områder, der kan beskrives ud fra den franske sociolog Pierre Bourdieus begreb om samfundets forskellige sociale rum, de såkaldte felter. Bourdieu bestemmer feltet som et netværk af sociale relationer, der sætter normer og rammer for den kunstneriske praksis og den enkelte udøvers arbejde. Metropolen er som litterært arkiv konfigureret omkring skiftende litterære felter, hvis urbane tekster både tematisk og formelt forholder sig til metropolens livsrum og oplevelsesformer. Men det er vigtigt at få fat $\mathrm{i}$, at metropolen opviser skiftende litterære felter, hvis litteratur både tematisk og formelt forbindes med metropolens livsrum og oplevelsesformer. Metropolens litterære kultur ændrer sine miljøer, og den urbane tekst formidles i mange slags kulturer og fascinerer og drager sine læsere. Den urbane tekst, der både kan forme sig som lyrik, kortprosa og roman, er et stykke storby af storbyen, som læseren oplever og fascineres eller frastødes af.

Litteraturens nyeste sted, der vokser og ændrer sit hastigt i det 21. århundrede, er internettet. På internettet optræder litteraturen i det, man med et begreb, der er udformet af litteraten og medieforskeren, Søren Pold, kan kalde "skriptede rum", der betegner, hvordan computerteknologien repræsenterer 
rum digitalt og samtidig vinder frem i den ydre, fysiske repræsentation af rum i nutidens omverden. De skriptede internetsteder eller rum står i forbindelse med og sætter præg på bogkulturen, også på biblioteker, uddannelses- og forskningsinstitutioner, på aviser, radio, tv og mobiltelefoni. De skriptede rum er konfigureret omkring hyperteksten, den digitale multilineære skrift, som er fuld af links til andre tekster, og som dermed forandrer den traditionelle lineære skrift og læsning, der er knyttet til bogen. Hypertekster kan dog ofte også oftest læses lineært.

Internettet har hurtigt bredt sig i den litterære kultur. Mange af nutidens litterære sider og digitale projekter forsvinder sikkert igen, men store dele af litteraturen og forfatterne er til stede i de nye genrer, nettet repræsenterer, og litteraturen tages i brug, skrives og læses her i stor målestok. Internettet fører til en større udbredelse og demokratisering af tilgangen til litteratur, men det skaber også kulturelle kløfter og afstand mellem dem, der er fortrolige med alle aspekter af teknologien, og dem, som ikke behersker den. Internettet vil sikkert komme ud for både op- og nedture, når det gælder kunstneres og forfatteres interesse for at bruge dets tekstformer og medier og litteratursteder, i lighed med de trykte bøger, de gamle traditioner for håndskrift og mundtlig overlevering og for ord og digte på sten og bygninger.

Når man arbejder med en stedsbaseret litteraturhistorie får man den fordel, at man kan give læseren en konkret fornemmelse af historiske perioder, tider og tekster. Man kan fortælle om stederne og de personer, der her har været med til at skrive og læse litteratur, og man kan dermed arbejde med det erkendelsespotentiale, som fortællingen har.

\section{FRA STED TIL STED \\ 4.1 FLERE PROJEKTER}

Jeg har bestemt ikke været ene om at forsøge at forny litteraturhistorieskrivningen. I de sidste 15 år er adskillige projekter blevet sat i værk både i og udenfor Norden. Pil Dahlerup udsendte i 1998 de to første bind af sit flerbindsværk, Dansk litteratur, vol I-II: Hun prioriterer en retorisk analyse af litteraturen og lægger vægt på først og fremmest at udvikle sikre definitioner og genrebestemmelser og fastholde selve det litterære objekt, ordets kunst. I hendes fremstilling skulle ikke korn- og smørpriserne, men litteraturen være hovedperson, som hun engang udtrykte det. Det store onewoman-projekt ser imidlertid ud til at tage sin tid, hvilket er forståeligt, eftersom der bliver lagt vægt på at gøre op med den a-teoretiske grundholdning til genren, der har været fremherskende i Danmark, og udvikle en videnskabeligt funderet litteraturhistorieskrivning (Dahlerup 1995:28).

Også andre nordiske litterater har siden 1990'erne forsøgt sig med at forny litteraturhistorieskrivningen. Det gælder Johan de Mylius, der i 1991 
udgav et bind af sine Anskuelsesformer, hvor han historisk studerer de oplevelser af verden, som litteraturen udtrykker på sin særlige måde. Fremstillingen gør ikke krav på at være nogen fuldstændig litteraturhistorie, men den beskriver litterære anskuelsesformer i tiden fra 1600-1800.

I 1997-1999 udkom en encyklopædisk, dansk litteraturhistorie, Laesninger $i$ dansk litteratur, vol. 1-5 med Povl Schmidt som hovedredaktør. Her blev der præsenteret enkeltstående historiske læsninger af hovedværker i dansk litteratur, forfattet af litteraturforskere fra forskellige universitetsmiljøer.

Den svenske litteraturprofessor Louise Vinge forestod i 1990'erne en litteraturhistorisk udgivelse, der mere var tænkt som en perspektiverende $\varnothing j e a ̊ b n e r$ end som en teoretisk stærk litteraturhistorisk konstruktion. Ikke desto mindre fik tobindsværket, Skånes Litteraturhistoria (1996-1997), formuleret perspektivrige pointer med sin vægtning af den regionale frem for den nationale kontekst. Værket åbnede for analyser af, hvorledes det litterære billede af Skåne, landskabet, folket, sproget og naturen er udformet og formidlet i en række forfatterskaber.

Den norske litteraturprofessor Per Thomas Andersen valgte på sin side at kombinere en teoretisk nyorientering med en ambition om komprimeret, oversigtspræget formidling og udgav 2001 étbindsværket Norsk litteraturhistorie. Her koncentrerede han sig mere om forfatternes kunstneriske værker end om deres biografi og lagde i øvrigt vægt på at placere norsk litteratur i en europæisk modernitetshistorisk sammenhæng. Den veloplagte formidling af en kronologisk oversigt spillede imidlertid en større rolle end den teoretiske dybdeboring i genrens problemer og muligheder. Men Per Thomas Andersen forsøgte dog i en kort form også at berige genren teoretisk.

Denne ambition må man savne $\mathrm{i}$ en flere nye danske, populært anlagte litteraturhistorier, der mere og mere former sig som en løst sammenbundet serie af skribent- og forfatterportrætter. Tendensen er også til stede i Dansk Litteraturs historie, vol. 1-5 (Mortensen \& Schack 2006-2009). Det enkelte bind er struktureret omkring en vekslen mellem korte kulturelle, politiske og kunstneriske optakter til forskellige tidsaldre, kortfattede periodeintroduktioner og mere fyldige portrætter af enkeltskribenter og forfatterskaber med et stadig mere udbredt mylder af navne og titler.

I en europæisk og amerikansk sammenhæng skrives der mange traditionelle litteraturhistoriske oversigtværker, men man finder også nybrydende litteraturhistorisk tænkning. Den store udgivelse fra Oxford University Press, The Oxford English Literary History (Stevenson et al. 20022005), slipper nationsbegrebet i bind 12, der omhandler perioden fra 19602000, ud fra en erkendelse af, at litteratur ikke længere kan opfattes som et produkt af en enkelt nations identitet. Man kan ikke skrive om Englands litteratur, men nok om engelsk litteratur, forstået som litteratur skrevet på engelsk fra mange verdensdele og nationer, der bliver til ud fra både lokale, 
nationale og internationale inspirationer. Nationen England skrumper, mens engelsk litteratur vokser i denne fremstilling.

Et andet opsigtsvækkende nytænkt arbejde med litteraturhistoriegenren er den store A New History of French Literature (1989), der først udkom på engelsk. Værket består af en række artikler, der er skrevet ud fra årstal og datoer og inddelt efter genre eller et tema: f.eks. opslaget 1095, der tager udgangspunkt $\mathrm{i}$, at pave Urban i en tale på kirkemødet i Clermont proklamerer det første korstog. Artiklen kaster sig herefter over epikken før og efter korstogene. Fremstillingen danner således en krønike, hvis afsnit er relativt korte og placerer litteraturen i forhold til politik, kunst og kultur. Som læser kommer man tæt på tekster og begivenheder, mens man har mere besvær med at skaffe sig et overblik. Redaktøren Denis Hollier argumenterer i forordet for den anvendte metode og fremhæver, at man i litteraturhistoriestudierne har været mest optaget af afgrænsningens problem: den romantiske litteraturhistorie afgrænser litteraturen i forhold til nation og sprog; den positivistiske afgrænser litteraturhistorieskrivningen fra dens objekt, litteraturen; den komparative litteraturhistorieskrivning, der sammenligner på tværs af nationer og sprog, afgrænser litteraturen og det litterære sprog fra andre slags tekst og sprog (Hollier 1989:xxiv).

Litteraturhistorieskrivningen har fokuseret på forholdet mellem litteraturens indre og dens ydre: tekst over for kontekst og forestillet sig, at man klart kunne skelne imellem det indre og det ydre. A New History of French Literature bygger imidlertid på ideen om, at man aldrig kan drage så skarpe linjer. Det er umuligt at skelne mellem form og baggrund. Konteksten er tekstualiseret. I dag bør man ikke spørge sig selv om, hvad litteratur er, men hvad den ikke er. Litteraturen vil være det hele, foruden at være sig selv, siger Hollier. Sproget er stadig et vigtigt parameter, men det er ikke længere snævert forbundet med nationsbygningen. Fransk litteratur skrives i høj grad også uden for Frankrig. Udgivelsen er siden fulgt op af blandt andet A New History of German Literature (Wellbery 2004), hvor det understreges, at fremstillingen er del af en refleksiv vending i litteraturhistorieskrivningen, idet den lægger vægt på konstant at tematisere sin fremstillingsform. Man arbejder desuden ud fra tre udgangspunkter: for det første er de enkelte opslag skrevet ud fra vidt forskellige metoder og tilgange; for det andet reflekteres der hele vejen igennem over begrebet "tysk" kulturelt, geografisk og sprogligt og for det tredje inddrages forskellige medier og genrer foruden det trykte bogmedie. Man vil vise, hvorledes sproglig og national identitet har varieret i de litterære aktiviteters igennem hele det historiske forl $ø b$, og hvorledes mange medier har været i brug (Wellbery 2004:xxiv).

Den traditionelle narrative fremstilling er forladt til fordel for en fascinerende detaljerigdom i de enkelte essays, og dog sniger fortællingen sig 
alligevel ind i fremstillingen i gennem de mange anekdoter, der er med til at gøre de korte essays labyrintiske som litteraturen selv. De store introduktioner til de to litteraturhistorier skrives tydeligvis under indtryk af de forskellige vendinger, som er fulgt i kølvandet på den sproglige vending og som måske forlænger den i forskellig retning. Wellbery taler om den refleksive 'vending', der indebærer, at man skriver med en kritisk metabevidsthed om litteraturhistorieskrivningens egen historie og dens teoretiske problematikker.

Et veloplagt forsøg på at forny det historiske studium og den historiske formidling fra en helt anden kant finder vi i den tyske/amerikansk Hans Ulrich Gumbrechts udgivelse, 1926. Ein Jahr am Rand der Zeit (1997/2001). Gumbrecht forsøger her ud fra en receptionsteoretisk forståelse at rekonstruere den situation, som litterære værker er produceret i. Gumbrechts værk er en hyperteksthistorie, hvor læseren igennem forskellige opslag og krydshenvisninger skal bevæge sig rundt i året 1926 og få en oplevelse af at være i selve dette år. Ifølge Gumbrecht er året ikke interessant, fordi det er særlig skelsættende, men fordi det er et af de år i det 20. århundrede, som historikere aldrig har givet en særlig tolkningsmæssig relevans. Et mylder af kulturelle og litterære detaljer træder frem i de forskellige opslag, og læseren får en oplevelse af den tid, da Kafka udgav kortprosatekster og Martin Heideggers hovedværk Sein und Zeit var i trykken.

Et nytænkt projekt, der er under tilblivelse, er A Comparative History of Nordic Literature. Værket, der omhandler nordisk litteraturhistorie, redigeres af Steven P. Sondrup, Brigham Young University og Mark B. Sandberg, University of California, Berkeley. Man arbejder her ud fra Mario Valdés og Linda Hutcheons ideer om de kulturelle knudepunkter og bruger dermed også stedet som et udgangspunkt. Værket udarbejdes af et meget stort hold af skribenter fra skandinavist-miljøer og litteraturvidenskabelige institutter over alt $i$ verden.

Selvom om mange studerende har svært ved at vise entusiasme for litteraturhistorien, ser forskernes således endnu ikke ud til at have givet op!

\subsection{AFSLUTNING}

Jeg skrev selv på det sidste kapitel til Hvor litteraturen finder sted på en togrejse i Polen, hvor jeg så kirker, skoler og cafeer glide forbi uden for vinduet. Mange af stederne, der forsvandt bag toget, var beslægtet med de litteratursteder, jeg har skrevet om i min litteraturhistorie og jeg tænkte over, hvordan stederne indgik i litterære strukturer og knudepunkter, der både virkeligt og virtuelt rakte langt ud over Polens grænser. Den ældgamle katedral, som netop forsvandt bagude, var jo i middelalderen del af et stort europæisk netværk, hvor også de danske katedraler indgik. Her skrev man krøniker og helgenlegender, der lignede dem, vi kender fra Danmark. Den 
krøllede avis på togsædet ledte min tanke hen på bladhusene, som fik deres store tid i Danmark i begyndelsen af det 20.århundrede. Måske var der også i dagens polske avis en litteraturanmeldelse eller et bidrag fra en digter. Litteraturstedernes netværk peger både ind og ud af den dansksprogede litteratur og gør mange slags sammenligninger mulige. Der er meget mere at opdage, og der bliver i den internationale forskerverden tænkt grundigt over, hvordan arbejdet kan gribes an.

\section{LITTERATURLISTE}

Andersen, Vilhelm \& Carl Petersen. 1924. Illustreret Dansk Litteraturhistorie. vol. I-IV, København: Nordisk forlag, s.1924-1934.

Andersen, Per Thomas. 2001. Norsk litteraturhistorie. Oslo: Universitetsforlaget.

- 2006. Identitetens geografi. Steder $i$ litteraturen fra Hamsun til Naipaul. Oslo: Universitetsforlaget.

Bachtin, Michail. 1998. Det dialogiska ordet. Göteborg: Anthropos.

Bourdieu, Pierre. 1996. The Rules of Art. Genesis and Structure of the Literary Field. Stanford: Stanford University Press.

Butler, Judith. 1990. Gender Trouble. New York: Routledge.

Casey, Edward S.1993. Getting Back into Place. Toward a Renewed Understanding of the Place-world. Bloomington \&Indianapolis: Indiana University Press.

- 1997 The Fate of Place. A Philosophical History. Berkley, Los Angeles, London: University of California Press.

Conrad, Flemming. 1996. Smagen og det nationale. Studier i dansk litteraturhistorieskrivning 1800-1860. København: Museum Tusculanum.

Dahlerup, Pil. 1998. Dansk litteratur. Middelalder, vol. I-II. København: Gyldendal.

De Man, Paul. 1971. 'Literary History and Literary Modernity', Blindness and the Insight. Minneapolis: University of Minnesota Press, pp. 143-166.

Foucault, Michel. 2005. Vidensarkaologien. Århus: Forlaget Philosophia

- 1998. Andre rum. Slagmark, nr. 27, pp. 87-96.

Gumbrech, Hans Ulrich. 2001. 1926. Ein Jahr am Rand der Zeit. Frankfurt am Main: Suhrkamp.

Hollier, Denis. 1989: A New History of French Literature. Cambridge Massachusetts, London: Harvard University Press.

Hutcheon, Linda \& Mario J. Valdés (red.). 2002. Rethinking Literary History. A Dialogue on Theory. Oxford, New York: Oxford University Press.

Jørgensen, Jens Anker (et al). 2005. Hovedsporet. Dansk litteraturs historie. København: Gyldendal.

Knudsen, Karin Esmann. 2009. Historiske fortcellinger. Historieformidling og litteratur. Odense: Syddansk Unversitetsforlag.

Kemp, Peter. 1995. Tid og fortalling. Introduktion til Paul Ricœeur. Århus: Aarhus Universitetsforlag.

Larsen, Svend Erik \& Mads Rosendahl Thomsen (red.). 2005. Litteraturhistoriografi. Århus: Aarhus Universitetsforlag.

Mai, Anne-Marie (ed.). 2000-2001. Danske digtere i det 20. århundrede, vol. I-III. København: Gads Forlag.

- 2009a. Historier frem for kanoner - Refleksioner over litteraturhistorieskrivning og historisk læsning, TijdSchrift voor Skandinavistiek, vol. 30 (2009), nr. 1, tilgængelig på 
internetadressen, http://dpc.uba.uva.nl/cgi/t/text/text-idx?c=tvs;sid=cbff7571473fcc $867 \mathrm{f}$ 174f84ddf62d34;tpl=browse-toc-30.tpl.

- 2009b. Hvor litteraturen finder sted - tanker om litteraturhistorieskrivning. Synsvinkler. nr. 40, p. 7-36.

- 2010-2011. Hvor litteraturen finder sted, vol. I-III. København: Gyldendal.

Mai, Anne-Marie \& Dan Ringgaard (red.). 2010. Sted. Århus: Aarhus Universitetsforlag.

Moretti, Franco. 1998. Atlas of the European novel, 1800-1900. London: Verso.

Mortensen, Klaus P. \& May Shack (red.). 2006-2009. Dansk litteraturs historie, København: Gyldendal.

Møller Jensen, Elisabeth (red.). 1993-1998. Nordisk kvindelitteraturhistorie, vol. 1-5. København: Rosinante.

Perkins, David. 1992. Is Literary History Possible? Baltimore and London: Johns Hopkins University Press.

Petersen. Niels Matthias. 1867-1871. Bidrag til den danske Literaturs Historie, vol. 1-5. København: Wøldikes Forlag.

Pold, Søren. 2004. Ex libris. Medierealistisk litteratur. Paris, Los Angeles \& cyperspace. Odense: Syddansk Universitetsforlag.

Ricœur, Paul. 1984-1988. Time and Narrative, vol. I-III. Chicago: University of Chicago Press.

- 2004. Memory, History, Forgetting. Chicago: University of Chicago Press.

Schmidt, Povl (red.) 1997-2000. Laesninger $i$ dansk litteratur, vol. I-V. Odense: Syddansk Universitetsforlag.

Steffens, Heinrich. 1996. Indledning til philosofiske forelaesninger, red. Johnny Kondrup. København: DSL. Hans Reitzels Forlag.

Stevenson, Randall (et al). 2002-2005. The Oxford English Literary History, vol. I-XII. New York: Oxford University Press.

Vinge, Louise (red). 1996-1997. Skånes litteraturhistoria, vol. I-II. Malmö: Malmö Corona.

Wellbery, David E. 2004. A New History of German Literature. Cambridge, Massachusetts: The Bellknap Press of Harvard University Press.

\author{
Anne-Marie Mai \\ Syddansk Universitet \\ Institut for Kulturvidenskaber \\ Campusvej 55 \\ DK-5230 Odense \\ Denmark \\ ammai@sdu.dk
}

